\title{
Does Black Carbon Contribute to Eutrophication in Large Lakes?
}

\author{
Moses Odhiambo ${ }^{1} \cdot$ Joyanto Routh ${ }^{1}$
}

Published online: 20 October 2016

(C) The Author(s) 2016. This article is published with open access at Springerlink.com

\begin{abstract}
Eutrophication is a major ecological crisis in water bodies. This is mainly driven by anthropogenic activities in the catchment that incorporate various nutrients. Input of nutrients can also be driven by atmospheric deposition, which has a large footprint that goes beyond local point source(s). In particular, black carbon (BC) can be a carrier of various nutrients and increase primary productivity in lakes. We need to monitor the input of $\mathrm{BC}$ in large water bodies to fully understand its role in driving primary productivity and change in trophic status.
\end{abstract}

\section{Commentary}

Black carbon (BC) is a product or residue resulting from incomplete combustion of carbonaceous material such as biomass and fossil fuels [1]. Biomass burning is the largest contributor of small carbonaceous materials (fine ash and volatile elements) to the troposphere, and it has a major effect on climate, primary productivity, and human health [2]. The production of $\mathrm{BC}$ from biomass burning contributes to the transfer of carbon (C) from active to passive pools in the global C cycle [3]. Both coal and biomass burning account for 60-80 \% of $\mathrm{BC}$ emissions in Africa and Asia, whereas vehicles with diesel engines contribute $70 \%$ of the emissions in Europe and North and Latin America [4]. Even though it has been suggested that $\mathrm{BC}$ is recalcitrant Middleburg et al. [5] provides evidence of decomposition of $\mathrm{BC}$ indicating its chemical and

Joyanto Routh joyanto.routh@liu.se

1 Department of Thematic Studies - Environmental Change, Linköping University, Linköping SE-58183, Sweden biological reactivity. Structure, surface chemistry, and the size of $\mathrm{BC}$ determine its overall reactivity. The affinity of other elements to attach to $\mathrm{BC}$ is due to its large surface area, and presence of carboxylic and hydroxyl groups [6]. In particular, soil dynamics controlling the availability of $\mathrm{C}$ affects the persistence and distribution of $\mathrm{BC}$ in the environment.

Black carbon can remain buried for thousands of years, but could be eventually transported to other areas depending on sorption, erosion, and transport in the catchment. Hence, BC is an important paleo-environmental proxy that can be used to understand the different environmental parameters and their relationships. For example, charcoal from biomass combustion has not only been used as an indicator of anthropogenic activities in the catchment but is also used for reconstructing climate [7]. Over the years, a number of studies have been published on BC flux and its concentrations in different environmental matrices across Europe, North America, and Asia that has helped in providing chronological information about $\mathrm{BC}$ deposition and its global inventory [8].

During combustion of biomass, simple molecules such as $\mathrm{CO}_{2}, \mathrm{H}_{2} \mathrm{O}, \mathrm{NO}, \mathrm{N}_{2} \mathrm{O}, \mathrm{N}_{2}$, polycyclic aromatic hydrocarbons (PAH), $\mathrm{BC}$, and other intermediate products are discharged to the atmosphere. Atmospheric deposition (AD) is a complex process driving the deposition of nitrogen $(\mathrm{N})$, phosphorous $(\mathrm{P})$, and $\mathrm{BC}$ that can either act solely or collectively to promote primary production and algal blooms in aquatic bodies. Additionally, $\mathrm{AD}$ is also responsible for transporting other important micronutrients that are responsible for eutrophication. For example, in the coast of northern California [9] and Mediterranean Sea [10], where iron (Fe) may be limiting, dry $\mathrm{AD}$ is responsible for driving harmful algal blooms.

The environmental impact of a rise in various combustion by-products in water bodies is profound. In particular, the exponential rise in atmospheric $\mathrm{BC}$ and its solar radiative effects can have unexpected impacts on aquatic life by 
stimulating primary productivity and $\mathrm{CO}_{2}$ production [11]. Black carbon also leads to the production of $\mathrm{NO}_{\mathrm{x}}$ [12], which is readily absorbed by phytoplankton and promotes primary production in aquatic systems [13]. Particles adsorbed to BC could be transported and released into the water column, where they are available for cyanobacteria and aquatic biota that trigger eutrophication [11]. In particular, when $\mathrm{BC}$ is dispersed into the aquatic environment, it contains more free energy sites that have a high affinity for various particles including nutrients [14]. Consistent with this, a worldwide study on different lake systems confirms atmospheric $\mathrm{P}$ input altering the stoichiometry in alpine lakes globally [15]. Likewise, input of P via dry deposition has been suggested in Lakes Victoria, Tanganyika, Tahoe, Erie, and Baikal and the East China Sea [16-18]. Studies by Jaworski et al. [19] and Zhang et al. [20] in Lake Tahoe firmly establish the causality and provide better understanding about the relationship between $\mathrm{BC}$ and eutrophication. The authors reported that algal blooms increased in the lake immediately after large forest fires. This was attributed to increased $\mathrm{AD}$ of $\mathrm{P}$ containing BC (ash) produced from biomass burning. Similarly, in Lake Simcoe, total organic carbon, which is a combination of organic carbon (OC) and $\mathrm{BC}$, was found to be a non-specific indicator of primary productivity [21].

While the exact amount of nutrients transported from biomass burning is unknown, recent studies indicate that atmospheric $\mathrm{P}$ input into Lake Malawi in East Africa is as much as the flux derived from fluvial sources draining into the African rift lakes [22]. Similarly, AD of nutrients in South East China Sea and Lake Baikal are strongly influenced by biomass burning that occurs in the surroundings $[16,17]$. The study by Gikuma-Njuru et al. [23] on Lake Victoria indicates an interesting fact. The authors reported that the main lake was a net exporter of dissolved inorganic P into Nyanza Gulf, which is in contrast to the paradigm that the Gulf is a major contributor of nutrients from the catchment into Lake Victoria. This can be only possible if $\mathrm{P}$ in the open lake is derived from other sources such as wet and dry AD. It is possible the source of these nutrients could be traced by studying the distribution of PAHs. For example, presence of PAHs and soot (pyrogenic C) has been used to trace petrogenic versus combustion-derived inputs into lake bodies [24, 25]. Likewise, concentration of phenanthrene, which is a pyrogenic PAH and a product of biomass burning have increased in the Lake Victoria basin since the 1970s [26]. These studies indicate that AD of nutrients and BC could influence primary productivity and water quality in large water bodies.

Increase of population and subsequent energy demand has led to deforestation and urban development that ultimately result in increased $\mathrm{BC}$ production from biomass burning and fossil fuel consumption. In the Lake Victoria basin, the highest concentrations of $\mathrm{BC}$ have been found in close proximity to urban and agricultural areas [27]. Moreover, based on ${ }^{210} \mathrm{~Pb}$ age dating, Odhiambo [27] found exponential increase of $\mathrm{BC}$ between the late nineteenth and early twentieth century in the basin. It seems there is direct correlation between $\mathrm{BC}$ accumulation and past historical events (i.e., arrival of the East African Railways and reclamation of wetlands) and occurrence of cyanobacteria blooms in Lake Victoria, which indicate a possible causality between eutrophication and $\mathrm{BC}$ inputs.

It has been reported that UV light helps in promoting chemical changes in $\mathrm{BC}$, thereby increasing the surface area for degradation by microorganisms including cyanobacteria [11]. Since most tropical lakes receive maximum light all year round, the levels of $\mathrm{BC}$ degradation and cyanobacterial production will thereby increase resulting in enhanced eutrophication. Cyanobacteria known to fix dissolved and atmospheric $\mathrm{N}$ were found to be more competitive and dominant in large lake bodies that commonly have low N:P ratios [26]. In the Baltic Sea, the proliferation of cyanobacteria was found to be consistent with high AD-N (Atmospherically Deposited Nitrogen) and other products of biomass combustion [28]. Evidently, the presence of AD-N, AD-P and BC in lakes promotes primary production and cyanobacterial growth. The cyanobacteria accumulate and literally "choke" the life in these water bodies causing various social, economic, and environmental problems. The integrated role of $\mathrm{BC}$ in the environment thus plays an important function in understanding the paradigms of eutrophication, climate science, agriculture, and tracing anthropogenic activities in the region.

\section{Compliance with Ethical Standards}

Conflict of Interest There is no conflict of interest.

Open Access This article is distributed under the terms of the Creative Commons Attribution 4.0 International License (http:// creativecommons.org/licenses/by/4.0/), which permits unrestricted use, distribution, and reproduction in any medium, provided you give appropriate credit to the original author(s) and the source, provide a link to the Creative Commons license, and indicate if changes were made.

\section{References}

1. Hammes K, Schmidt MWI, Smernik RJ, Currie LA, Ball WP, Nguyen TH, P Louchouarn. Comparison of quantification methods to measure fire-derived (black-elemental) carbon in soils and sediments using reference materials from soil, water, sediment and the atmosphere. Global Biogeochem Cycles. 2007;21:1-18.

2. Akagi SK, Yokelson RJ, Wiedinmyer C, Alvarado MJ, Reid JS, Karl T, Crounse JD, Wennberg PO. Emission factors for open and domestic biomass burning for use in atmospheric models. Atmos Chem Physics. 2011;11: 4039-72. 
3. Boot CM, Haddix M, Paustian K, Cotrufo MF. Distribution of black carbon in Ponderosa pine forest floor and soils following the High Park wildfire. Biogeosciences. 2015;12:3029-39.

4. Bond TC, Doherty SJ, Fahey DW, Forster PM, Berntsen T, Deangelo BJ, et al. Bounding the role of black carbon in the climate system: a scientific assessment. J Geophy Res Atmos. 2013;118: 5380-552.

5. Middleburg J, Nieuwenhuize J, P van Breugel. Black carbon in marine sediments. Mar Chem 1999;65:245-52.

6. Thanh B, Ae N, Lehmann J, Kinyangi J, Smernik R, Riha SJ, Engelhard MH. Long-term black carbon dynamics in cultivated soil. Biogeochemistry. 2009;92:163-76.

7. Nelson DM, D Verschuren, MA Urban, FS Hu. Long-term variability and rainfall control of Savanna fire regimes in equatorial east Africa. Global Change Biol. 2012;18:3160-70.

8. Ruppel MM, Gustafsson Ö, Rose NL, Pesonen A, Yang H, Weckström J, Palonen V, Oinonen MJ, Korhola A. Spatial and temporal patterns in black carbon deposition to dated Fennoscandian Arctic Lake sediments from 1830 to 2010. Environ Sci Technol. 2015;49:13954-63.

9. Anderson DM, Glibert PM, Burkholder JM. Harmful algal blooms and eutrophication: nutrient sources, composition, and consequences. Estuaries. 2002;25:704-26.

10. Carbo P, Krom MD, Homoky WB, Benning LG, Herut B. Impact of atmospheric deposition on $\mathrm{N}$ and $\mathrm{P}$ geochemistry in the Southeastern Levantine Basin. Deep-Sea Resch. 2005;52:3041-53.

11. Malits A, Cattaneo R, Sintes E, Josep MG, Henrdl GJ, Weinbauer M. Potential impacts of black carbon on the marine microbial community. Aquat Microbial Ecol. 2015;75:27-42.

12. Accardi-Dey A, Gschwend PM. Assessing the combined roles of natural organic matter and black carbon as sorbents in sediments. Environ Sci Technol. 2002;36:21-29.

13. Paerl HW, Dennis RL, Whitall DR. Atmospheric deposition of nitrogen: Implications for nutrient over-enrichment of coastal waters. Estuaries. 2002;25:677-93.

14. Koelmans AA, Jonker MTO, G Cornelissen, TD Bucheli, PCM. van Noort, Gustafsson Ö. Black carbon: The reverse of its dark side. Chemosphere. 2006;63:365-77.

15. Brahney J, Ballantyne AP, Turner BL, Spaulding S, Otu M, Neff JC. Separating the influences of diagenesis, productivity and anthropogenic nitrogen deposition on sedimentary $\delta 15 \mathrm{~N}$ variations. Org Geochem. 2014;75:140-50.

16. Kobanova GI, Takhteev VV, Rusanovskaya OO, Timofeyev MA. Lake Baikal ecosystem faces the threat of eutrophication. Internat $\mathbf{J}$ Ecology. 2016;2016:1-7.
17. Ding K, Liu J, Ding A, Liu Q, Zhao TL, Shi J, Han Y, Wang H, Jiang F. Uplifting of carbon monoxide from biomass burning and anthropogenic sources to the free troposphere in East Asia. Atmos Chem Physics. 2015;15:2843-66.

18. Tamatamah RA, Hecky RE, Duthie HC. The atmospheric deposition of phosphorus in Lake Victoria (East Africa). Biogeochemistry. 2005;73:325-44.

19. Jaworski, NA, Howarth RW, Hetling LJ. Atmospheric deposition of nitrogen oxides onto the landscape contributes to coastal eutrophication in the Northeast United States. Environ Sci Technol. 1997;31:1995-2004.

20. Zhang Q, Carroll JJ, Dixon AJ, Anastasio C. Aircraft measurements of nitrogen and phosphorus in and around the Lake Tahoe Basin: Implications for possible sources of atmospheric pollutants to Lake Tahoe. Environ Sci Technol. 2002;36:4981-89.

21. Brown LJ, Taleban V, Gharabaghi B, Weiss L. Seasonal and Spatial distribution patterns of atmospheric phosphorus deposition to Lake Simcoe, ON. J Great Lakes Resch. 2011;37:15-25.

22. Hecky RE, Bootsma HA, Odada EO. African lake management initiatives: The global connection. Lakes Reserv Res Manag. 2006;11:203-13.

23. Gikuma-Njuru P, RE Hecky, SJ Guildford, S Macintyre. Spatial variability of nutrient concentrations, fluxes, and ecosystem metabolism in Nyanza Gulf and Rusinga Channel, Lake Victoria [East Africa]. Limnol Oceanogr. 2013;58:774-89.

24. Das SK, Routh J, Roychoudhury AN. Sources and historic changes in polycyclic aromatic hydrocarbon input in a shallow lake, Zeekoevlei, South Africa. Org Geochem. 2008;39:1109-12.

25. Routh J, Meyers PA, Gustafsson Ö, Baskaran M, Hallberg R, Schöldstrom A. Sedimentary geochemical record of humaninduced environmental changes in the Lake Brunnsviken watershed, Sweden. Limnol Oceanogr. 2004;49:1560-69.

26. Stager JC, Hecky RE, Grzesik D, Cumming BF, Kling H. Diatom evidence for the timing and causes of eutrophication in Lake Victoria, East Africa. Hydrobiologia. 2009;636:1-16.

27. Odhiambo, MA. Distribution of black carbon and its impact on eutrophication in Lake Victoria. Retrieved from Digitala Vetenskapliga Arkivet. (MSc thesis, 2016) Accession No. diva2 :954113.

28. Paerl HW, Whitall DR. Anthropogenically-derived atmospheric nitrogen deposition, marine eutrophication and harmful algal bloom expansion: Is there a link? Ambio. 1999;28:307-11. 